\title{
ENTHALPY-ENTROPY COMPENSATION BASED ON ISOTHERMS OF MANGO
}

\author{
Javier TELIS-ROMERO ; Márcio N. KOHAYAKAWA; ; Vivaldo SILVEIRA JR ;
}

\author{
Maria A. M. PEDRO ; Ana L. GABAS
}

\section{SUMMARY}

ENTHALPY-ENTROPY COMPENSATION BASED ON ISOTHERMS OF MANGO. Moisture equilibrium data of mango pulp were determined using the static gravimetric method. Adsorption and desorption isotherms were obtained in the range of 30-70 $\mathrm{C}$, to water activities $\left(a_{w}\right)$ from 0.02 to 0.97 . The application of the GAB model to the experimental results, using direct nonlinear regression analysis, provided agreement between experimental and calculated values. The net isosteric heat of sorption was estimated from equilibrium sorption data, using the Clausius-Clapeyron equation. Isosteric heats of sorption were found to increase with increasing temperature and could be well adjusted by an exponential relationship. The enthalpy-entropy compensation theory was applied to sorption isotherms and plots of $\Delta \mathrm{H}$ versus $\Delta \mathrm{S}$ provided the isokinetic temperatures, indicating an enthalpy controlled sorption process.

Keywords: moisture content; thermodynamic properties; mango.

\section{RESUMO}

COMPENSAÇÃO ENTALPIA-ENTROPIA BASEADA NAS ISOTERMAS DE MANGO. Dados de equilibrio da umidade da polpa de manga foram determinados utilizando-se o método estático gravimétrico. As isotermas de adsorção e dessorção foram obtidas na faixa de $30-70 \mathrm{C}$ e as atividades de água (a ) de 0,02 a 0,97. A utilização do modelo de GAB nos resultados experimentais, através da análise de regressão não linear, proporcionou um bom ajuste entre os dados experimentais e os valores calculados. O calor isostérico de sorção foi estimado a partir dos dados de equilibrio de sorção, utilizando-se a equação de Clausius-Clayperon. Notou-se que os calores isostéricos de sorção crescem com o aumento da temperatura e pode ser bem ajustado através de uma relação exponencial. A teoria da compensação entalpia-entropia foi aplicada às isotermas de sorção e gráficos $\Delta \mathrm{H}$ versus $\Delta \mathrm{S}$ forneceram as temperaturas isocinéticas, indicando um processo de sorção entalpicamente controlado.

Palavras-chave: umidade; propriedades termodinâmicas; manga.

\section{1 - INTRODUCTION}

The mango (Mangifera indica) is a tropical fruit, originally from the South of Asia, and it is available worldwide today.

In 2000, Asian countries dominated the market of mango in natura, achieving about $76.3 \%$ of the world production. India (15.642 thousand tons) and China (3.307 thousand tons) represent more than $60 \%$ of the production. In America, Mexico is the third world producer of mango with about 1.5 million tons, followed by Brazil ( $8^{\text {'" }}$ in world ranking) producing 500 thousand tons [6].

The gender Mangifera contains 41 species and belongs to the same family as the cashew tree. The mango is rich in vitamin A and contains reasonable amounts of vitamins $B$ and $C$, as well as minerals, mainly iron [17].

Recebido para publicação em 23/12/2003. Aceito para publicação em 21/03/2005(001269).

Depto. de Engenharia e Tecnologia de Alimentos - Universidade Estadual Paulista. CEP: 15054-000, São José do Rio Preto, SP.

Depto. de Engenharia de Alimentos - Universidade Estadual de Campinas. C.P.: 6121, CEP: 13083-970, Campinas, SP.

Depto. de Engenharia de Alimentos, Universidade de São Paulo. C.P.: 23. E-mail:gabas@usp.br. CEP: 13635-900, Pirassununga, SP. A quem a correspondência deve ser enviada.
The mango is consumed mainly in natura, but can be also industrialized as pulps, jellies, juices and dehydrated fruits.

Knowledge of water sorption isotherms and isosteric heat of sorption is essential to various food processes such as drying, storage and packaging. They give information about the water sorption mechanism and interactions between food components and water. They also help to establish the final moisture content and permit the estimation of energy requirements of drying processes.

Several researchers have determined water sorption isotherms for various products and temperatures and selected ranges of water activity $[8,21,27]$. Empirical and semi-empirical equations have been proposed to correlate the equilibrium moisture content with water activity of food products. The GAB (GuggenheimAnderson-deBoer) equation has been suggested as the most versatile sorption model available in the literature and has been applied successfully to various dehydrated foods [12,27]. It is based on the BET (Brunauer-EmmettTeller) theory and involves three coefficients which have physical significance, two of them being functions of temperature [18].

A promising theory that has been widely considered to investigate physical and chemical phenomena 
involved in water sorption $[1,16]$ is enthalpy-entropy compensation or isokinetic theory, which was originally applied by BELL [4]. The isokinetic theory is an important tool in recognizing different mechanisms for water sorption under varying conditions, such as drying processes [22]. Changes in enthalpy $(\Delta \mathrm{H})$ may provide a measure of changes in energy occurring upon mixing of water molecules with sorbent during sorption processes. Entropy changes $(\Delta S)$ may also be associated with the binding or repulsive forces in the system. Gibbs free energy $(\Delta G)$ may be indicative of the affinity of sorbents for water and provides a criterion whether water sorption occurs as a spontaneous process. AGUERRE, SUAREZ \& VIOLLAZ [1] applied enthalpy-entropy compensation to derive a two parameter sorption equation which takes into account the effect of temperature on water sorption isotherms of some food products. FERRO-FONTAN et al. [7] suggested the existence of a linear relationship between enthalpy and entropy for water sorption in some foods.

The purpose of the present work was to determine the heats of water vapor adsorption and desorption in mango pulp by means of sorption isotherms at different temperatures, as well as to analyze its effects in food process optimization.

\section{1 - Mathematical development}

\subsection{1 - GAB model}

The GAB is a relatively simple model with a small number of parameters, which have physical meaning, and can be applied to a wide range of water activities. It is mathematically expressed as [22]:

$$
X=\frac{(C-1) K a_{w} X_{m}}{1+(C-1) K a_{w}}+\frac{K a_{w} X_{m}}{1-K a_{w}}
$$

where $\mathrm{X}_{\mathrm{m}}$ is the moisture content (dry basis) corresponding to an adsorbed monolayer (BET) and $\mathrm{C}$ and $\mathrm{K}$ are constants related to the temperature effect.

$$
\begin{gathered}
\mathrm{C}=\mathrm{C}_{\mathrm{o}} \exp \left(\frac{\Delta \mathrm{H}_{\mathrm{c}}}{\mathrm{RT}}\right) \\
\mathrm{K}=\mathrm{k}_{\mathrm{o}} \exp \left(\frac{\Delta \mathrm{H}_{\mathrm{k}}}{\mathrm{RT}}\right)
\end{gathered}
$$

where $\Delta \mathrm{H}$ and $\Delta \mathrm{H}$ are functions of the heat of sorption of water: $\Delta \mathrm{H}=\mathrm{H}-\mathrm{H}_{\mathrm{s}}$ and $\Delta \mathrm{H}=\lambda-\mathrm{H}_{\mathrm{s}}$. In the above expressions $\mathrm{C}$ and $\mathrm{k}$ are adjusted constants for the temperature effect; $\mathrm{H}_{m}$ and $\mathrm{H}$ are the heats of sorption of the monolayer and the multilayer of water respectively, and $\lambda$ is the heat of condensation of pure water.

The parameters can be estimated by fitting the mathematical model to the experimental data, using nonlinear regression.

\subsection{2 - Thermodynamic properties}

The net isosteric heat of sorption or enthalpy of sorption ( $\mathrm{q}$ ) is defined as the difference between the total heat of sorption $\left(Q_{\text {. }}\right)$ and the heat of water vaporization. It can be determined from the following equation, which is derived from the Clausius-Clapeyron equation [22]:

$$
\left.\frac{\partial \ln \left(\mathrm{a}_{\mathrm{w}}\right)}{\partial(1 / \mathrm{T})}\right|_{\mathrm{X}}=-\frac{\mathrm{Q}_{\mathrm{st}}-\lambda}{\mathrm{R}}=-\frac{\mathrm{q}_{\mathrm{st}}}{\mathrm{R}}
$$

The isosteric heat of sorption is a differential molar quantity derived from the temperature dependence of the isotherm. This approach assumes that the net isosteric heat is invariable with temperature and the application of this method requires the measurement of sorption isotherms at two or more temperatures [20].

The change in molar differential entropy of desorption can be calculated from Gibbs-Helmholtz equation as used by [22]:

$$
\Delta \mathrm{S}=\frac{\Delta \mathrm{H}-\Delta \mathrm{G}}{\mathrm{T}}
$$

where the free energy is calculated as

$$
\Delta \mathrm{G}=\mathrm{RT} \ln \mathrm{a}_{\mathrm{w}}
$$

The effect of a change in water sorption on free energy is usually accompanied by changes on both the enthalpy and the entropy. Substituting equation (6) in (5) and rearranging, it results in:

$$
\ln \mathrm{a}_{\mathrm{w}}=\frac{\Delta \mathrm{H}}{\mathrm{RT}}-\frac{\Delta \mathrm{S}}{\mathrm{R}}
$$

Then, the isosteric heat of sorption or enthalpy of sorption and entropy can be calculated from equation (7) by plotting $\ln$ a versus $1 / \mathrm{T}$ for certain values of the material moisture content and then determining the slope $(-\Delta H / R)$ and the linear coefficient $(\Delta S / R)$. This procedure is repeated for many values of $\mathrm{X}$, in order to detect the dependence of $\mathrm{q}$. on the moisture content. Several researchers used the above procedure for the determination of q. . TSAMI [25] calculated the heat of sorption of water for dried fruits, KIRANOUDIS et al. [11] for some vegetables, MADAMBA, DRISKOLL \& BUCKLE [16] for garlic and MCLAUGHLIN \& MAGEE [20] for potatoes.

A plot of $\Delta \mathrm{H}$ versus $\Delta \mathrm{S}$ from values of equation (7) for the pulp of mango can be evaluated for each set of sorption data. These values can be correlated according to the following equation [5]:

$$
\Delta \mathrm{H}=\mathrm{T}_{\mathrm{B}}(\Delta \mathrm{S})+\Delta \mathrm{G}_{\mathrm{B}}
$$

The isokinetic temperature, $\mathrm{T}_{\mathrm{a}}$, has an important physical meaning as it represents the temperature at 
which all reactions in the series proceed at the same rate. Since there is a high degree of linear correlation between enthalpy and entropy, the compensation theory was assumed to be valid for sorption [16]. KRUG, HUNTER \& GRIEGER [13,14] recommended a test for the compensation theory, which involves comparing the isokinetic temperature with the harmonic mean temperature $\mathrm{T}_{\mathrm{hm}}$, which is defined as:

$$
\mathrm{T}_{\mathrm{hm}}=\frac{\mathrm{n}}{\sum_{\mathrm{i}=1}^{\mathrm{n}}(1 / \mathrm{T})}
$$

An approximate $(1-\alpha) 100$ percent confidence interval for $\mathrm{T}_{\mathrm{v}}$ may be calculated from:

$$
\mathrm{T}_{\mathrm{B}}=\mathrm{T}_{\mathrm{B}} \pm \mathrm{t}_{\mathrm{m}-2, \alpha / 2} \sqrt{\operatorname{Var}\left(\mathrm{T}_{\mathrm{B}}\right)}
$$

where:

$$
\begin{gathered}
T_{B}=\frac{\sum(\Delta H-\overline{\Delta H})(\Delta S-\overline{\Delta S})}{\sum(\Delta S-\overline{\Delta S})^{2}} \\
\operatorname{Var}\left(T_{B}\right)=\frac{\sum\left(\Delta H-\overline{\Delta G}_{B}-T_{B} \Delta S\right)^{2}}{(m-2) \sum(\Delta S-\overline{\Delta S})^{2}}
\end{gathered}
$$

$m$ is the number of $((\Delta \mathrm{H}),(\Delta \mathrm{S}))$ data pairs, $(\overline{\Delta H})$ is the average enthalpy, and $(\overline{\Delta S})$ the average entropy.

\section{2 - MATERIAL \& METHODS}

\section{1 - Raw material}

Samples of mango (Mangifera indica L.) Haden variety were kept in a cold room at $7 \mathrm{C}$ prior to their use. The mangos was peeled and the pulp cut in small pieces until reaching a pulp. Sorption isotherms were determined for the pulp only. The composition of the mango pulp was determined and the main results are shown as follow: soluble solids: $8^{\circ}$ Brix; total acidity: $0.35 \mathrm{~g} / 100 \mathrm{~g}$; total sugars: $17 \mathrm{~g} / 100 \mathrm{~g}$ and $\mathrm{pH}: 3.3$.

\section{2 - Sorption isotherms}

The equilibrium moisture content of pulp at several temperatures was determined by the static gravimetric method [10], following adsorption and desorption procedures, in the temperature range of $30-70^{\circ} \mathrm{C}$. Adsorption isotherms were obtained with samples dehydrated at $60^{\circ} \mathrm{C}$ to constant weight. Nine saturated salt solutions were prepared corresponding to a range of water activities from 0.02 to 0.97 . Each solution was transferred into separated jars in an amount to occupy a space of about $1.5 \mathrm{~cm}$ depth at the bottom. Duplicate samples were weighed into small plastic receptacles and placed on tripods in the jars, which were then tightly closed and placed in a temperature-controlled chamber. The required equilibration time was 4 to 5 weeks based on the change in weight expressed on a dry basis, which did not exceed $0.1 \% \quad(0.001 \mathrm{~g} / \mathrm{g}$ dry solids). The equilibrium moisture content was determined by the vacuum oven method [2].

\section{3 - RESULTS \& DISCUSSION}

\section{1 - Sorption isotherms}

Equilibrium moisture contents versus water activity for mango pulp in the range of temperatures examined are shown in Tables $1 a$ and $1 b$. The moisture content at each water activity represents the mean value of two replications, each replicate being the mean of five samples.

The behavior of the curves for adsorption and desorption at 30,50 and $70 \mathrm{C}$ is shown in Figures 1 and 2 , respectively. It can be seen that the equilibrium moisture content presented a little increase with decreasing temperature at constant water activity, for both figures. This behavior is generally ascribed to a reduction in the number of active sites due to chemical and physical changes induced by temperature; the extent of decrease, therefore, depends on the nature or constitution of the food [22].

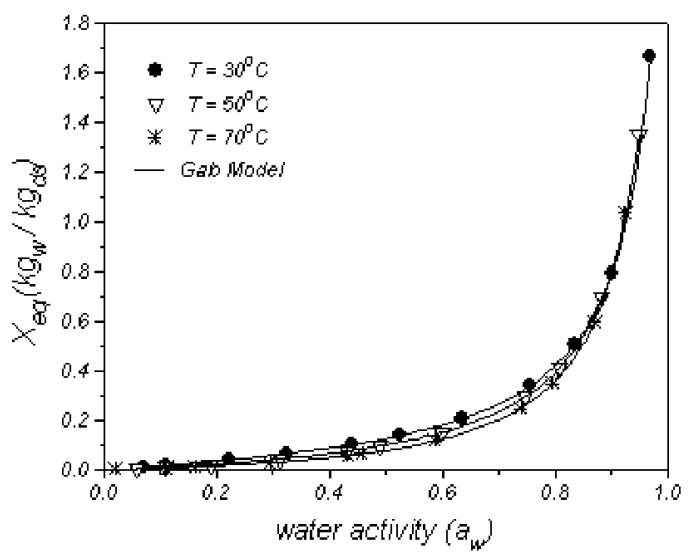

FIGURE 1 - Adsorption isotherms of mango pulp at different temperatures

A marked intersection of the isotherms and the inverse temperature effect was not observed for mango fruit, but there was a tendency for this 'crossing-over' at higher water activities. According to AYRANCI, AYRANCI $\&$ ZAFER [3], products which have high sugar content, such as dried apricots, dried figs and raisins showed intersection of the curves, since more sugar was being dissolved and thus more water was being held by these food products at higher temperatures. They also proposed that isotherm crossing behavior may not be 


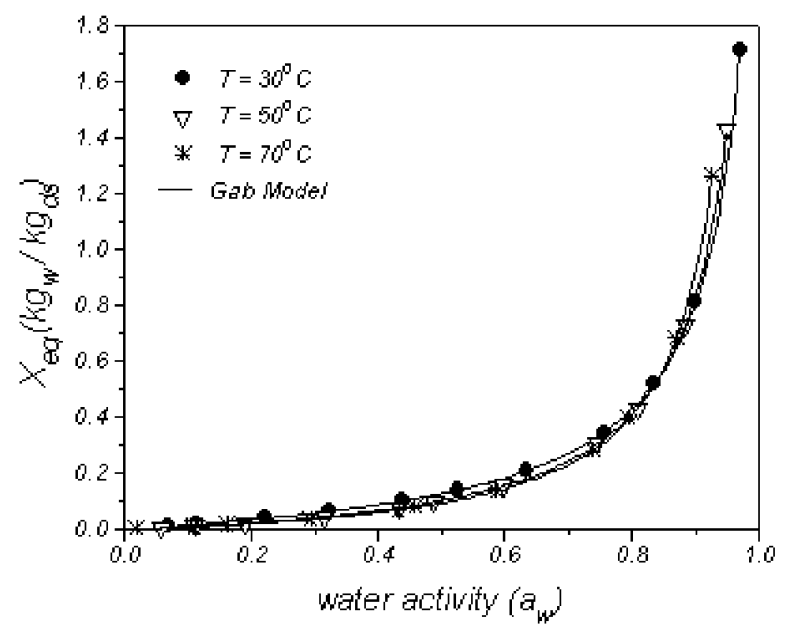

FIGURE 2 - Desorption isotherms of mando pulp at different temperatures

observed for fresh fruits since sugar should already be in dissolved form throughout the whole water activity range. However, GABAS, TELIS-ROMERO \& MENEGALLI [8] found an isotherm-crossing behavior for grapes even in desorption and in water activities as low as 0.75 .

TABLE 1a - Experimental equilibrium water contents $(\mathrm{kg}$ water $/ \mathrm{kg}$ dry matter) for mango at 30,40 and $50^{\circ} \mathrm{C}$

\begin{tabular}{|c|c|c|c|}
\hline $\begin{array}{l}\text { Temp } \\
\left({ }^{\circ} \mathrm{C}\right)\end{array}$ & $\begin{array}{c}\text { Water } \\
\text { Activity }\end{array}$ & Adsorption & Desorption \\
\hline \multirow{11}{*}{30} & 0.069 & 0.011 & 0.011 \\
\hline & 0.112 & 0.019 & 0.019 \\
\hline & 0.223 & 0.042 & 0.042 \\
\hline & 0.324 & 0.066 & 0.066 \\
\hline & 0.439 & 0.103 & 0.103 \\
\hline & 0.526 & 0.140 & 0.141 \\
\hline & 0.635 & 0.208 & 0.210 \\
\hline & 0.756 & 0.341 & 0.346 \\
\hline & 0.835 & 0.509 & 0.518 \\
\hline & 0.900 & 0.793 & 0.810 \\
\hline & 0.970 & 1.667 & 1.711 \\
\hline \multirow{11}{*}{40} & 0.066 & 0.009 & 0.009 \\
\hline & 0.111 & 0.015 & 0.015 \\
\hline & 0.206 & 0.031 & 0.031 \\
\hline & 0.319 & 0.055 & 0.055 \\
\hline & 0.432 & 0.088 & 0.089 \\
\hline & 0.506 & 0.117 & 0.119 \\
\hline & 0.615 & 0.178 & 0.182 \\
\hline & 0.753 & 0.322 & 0.332 \\
\hline & 0.820 & 0.457 & 0.475 \\
\hline & 0.893 & 0.750 & 0.784 \\
\hline & 0.961 & 1.541 & 1.636 \\
\hline \multirow{11}{*}{50} & 0.059 & 0.006 & 0.006 \\
\hline & 0.110 & 0.012 & 0.012 \\
\hline & 0.189 & 0.023 & 0.023 \\
\hline & 0.314 & 0.046 & 0.046 \\
\hline & 0.432 & 0.077 & 0.078 \\
\hline & 0.489 & 0.098 & 0.099 \\
\hline & 0.599 & 0.153 & 0.157 \\
\hline & 0.746 & 0.295 & 0.305 \\
\hline & 0.809 & 0.415 & 0.431 \\
\hline & 0.884 & 0.695 & 0.731 \\
\hline & 0.949 & 1.355 & 1.425 \\
\hline
\end{tabular}

TABLE 1b - Experimental equilibrium water contents $(\mathrm{kg}$ water $/ \mathrm{kg}$ dry matter) for mango at 60 and $70^{\circ} \mathrm{C}$

\begin{tabular}{cccc}
\hline $\begin{array}{c}\text { Temp } \\
\left({ }^{\circ} \mathrm{C}\right)\end{array}$ & $\begin{array}{c}\text { Water } \\
\text { Activity }\end{array}$ & Adsorption & Desorption \\
\hline & 0.045 & 0.004 & 0.004 \\
& 0.110 & 0.010 & 0.010 \\
& 0.175 & 0.017 & 0.017 \\
60 & 0.307 & 0.038 & 0.038 \\
& 0.432 & 0.067 & 0.068 \\
& 0.473 & 0.080 & 0.082 \\
& 0.590 & 0.133 & 0.136 \\
& 0.740 & 0.269 & 0.278 \\
& 0.800 & 0.378 & 0.392 \\
& 0.876 & 0.643 & 0.673 \\
70 & 0.936 & 1.173 & 1.246 \\
\hline & 0.020 & 0.001 & 0.004 \\
& 0.110 & 0.008 & 0.010 \\
& 0.162 & 0.013 & 0.017 \\
& 0.294 & 0.030 & 0.038 \\
& 0.432 & 0.059 & 0.068 \\
& 0.458 & 0.066 & 0.082 \\
& 0.587 & 0.118 & 0.137 \\
& 0.739 & 0.250 & 0.280 \\
& 0.795 & 0.349 & 0.395 \\
& 0.870 & 0.600 & 0.683 \\
& 0.925 & 1.038 & 1.264 \\
\hline
\end{tabular}

The results of direct nonlinear regression analysis of fitting the GAB equation to the experimental points are shown in Table 2. The fit determination coefficient, $\mathrm{r}^{2}$, was found to be satisfactory $(r>0.99)$.

TABLE 2 - Estimated GAB parameters for mango pulp

\begin{tabular}{lccccccc}
\hline & $\begin{array}{c}\mathrm{X}_{\mathrm{m}} \\
(\% \text { dry } \\
\text { basis })\end{array}$ & $\begin{array}{c}\mathrm{C}_{0} \\
\left(\times 10^{3}\right)\end{array}$ & $\begin{array}{c}\Delta \mathrm{H}_{\mathrm{c}} \\
(\mathrm{kJ} / \mathrm{mol})\end{array}$ & $\mathrm{k}_{\mathrm{o}}$ & $\begin{array}{c}\Delta \mathrm{H}_{\mathrm{k}} \\
(\mathrm{kJ} / \mathrm{mol})\end{array}$ & $\mathrm{r}_{\mathrm{c}}^{2}$ & $\mathrm{r}_{\mathrm{k}}^{2}$ \\
\hline Adsorption data & 11.8 & 0.60 & 19.45 & 1.11 & -0.374 & 0.98 & 0.98 \\
& & & & & & & \\
Desorption data & 12.5 & 3.71 & 14.65 & 1.27 & -0.720 & 0.82 & 0.82
\end{tabular}

\section{2 - Sorption thermodynamic properties}

The net isosteric heats of sorption were determined by applying the equation (4) obtained from adsorption and desorption isotherms. The results for mango are given in Table 3 and clearly show a marked increase in isosteric heats with decreasing moisture contents. The elevated net heats of sorption of water at low moisture contents are an indication of strong water-food component interactions in the fruit. As the moisture content increases, the available sites for sorption of water reduce, resulting in lower values of $q$.

Similar effects of moisture content on the heats of sorption were reported by SARAVACOS TSIOURVAS \& TSAMI [23] for sultana raisins and by MAZZA \& LEMAGUER [19] for yellow globe onion. According to WANG \& BRENNAN [26] the decrease in the isosteric heats with higher amounts of sorbed water can be quantitatively explained by considering that, initially, sorption occurs on the most active available sites giving rise to high interaction energy. As these sites become occupied, sorption occurs on the less active ones, resulting in lower heats of sorption. 
It can be also observed in Table 3 that the values of net isosteric heats of adsorption are a little higher than those of desorption, indicating that energy involved in the adsorption process is greater than that in desorption process. It can be important for the drying process of mango.

IGLESIAS \& CHIRIFE [9] compared the isosteric heats of water adsorption and desorption for a large number of foods. In general, heats of desorption were significantly higher than adsorption at low moisture contents. On further sorption, the difference decreased and practically disappeared at high moisture contents. Several theories have been advanced to explain the phenomenon of hysteresis. It is believed that it is not possible to give a simple explanation of this phenomenon in foods, since each food is a complex combination of various constituents, which not only can sorb water independently, but can also interact among themselves giving rise to different water-sorbing capacities.

TABLE 3 - Net isosteric heat of sorption for mango pulp

\begin{tabular}{ccc}
\hline \multirow{2}{*}{$\begin{array}{c}\mathrm{X} \\
\text { \% dry basis })\end{array}$} & Adsorption & Desorption \\
\cline { 2 - 3 } & & $\begin{array}{c}\mathrm{q}_{\mathrm{st}} \\
(\mathrm{kJ} / \mathrm{mol})\end{array}$ \\
\hline 4 & 10.0 & 8.6 \\
8 & 6.2 & 5.4 \\
10 & 5.1 & 4.5 \\
15 & 3.3 & 2.9 \\
20 & 2.2 & 1.9 \\
25 & 1.6 & 1.4 \\
30 & 1.2 & 0.9 \\
40 & 0.6 & 0.5 \\
50 & 0.3 & 0.2 \\
60 & 0.2 & 0.1 \\
70 & 0.1 & 0.1 \\
80 & 0.1 & 0.1 \\
\hline
\end{tabular}

An empirical exponential relationship between the isosteric heat of sorption and the moisture content, as proposed by TSAMI et al.[24] was fitted to the results, according to equation (13).

$$
\mathrm{q}_{\mathrm{st}}=\mathrm{q}_{\mathrm{o}} \exp \left(-\mathrm{X}_{\mathrm{eq}} / \mathrm{X}_{\mathrm{o}}\right)
$$

where $\mathrm{q}$ is the isosteric heat of sorption at the first water molecule, $\mathrm{X}_{\text {in }}$ is the equilibrium moisture content, and $\mathrm{X}$ is taken as the characteristic moisture content of a food material.

Table 4 shows the constants $\mathrm{q}$ and $\mathrm{X}$ and the values of the fit determination coefficient $\left(\mathrm{r}^{2}\right)$, which are satisfactory. In general, the calculated values of these constants were slightly higher for desorption than for adsorption. A similar variation of these constants was observed by TSAMI et al. [24] for sultana raisins, figs, prunes and apricots.

From the straight lines calculated by equation (7) at different moisture contents of the mango, the values of $\Delta \mathrm{H}$ and $\Delta \mathrm{S}$ were obtained. A plot of enthalpy versus
TABLE 4 - Estimated parameters of the empirical equation (13) for mango

\begin{tabular}{lccc}
\hline & $\begin{array}{c}\mathrm{q}_{\mathrm{o}} \\
(\mathrm{kJ} / \mathrm{mol})\end{array}$ & $\begin{array}{c}\mathrm{X}_{\mathrm{o}} \\
(\% \text { dry basis })\end{array}$ & $\mathrm{R}^{2}$ \\
\hline Adsorption data & 12.1 & 10.69 & 0.989 \\
Desorption data & 14.0 & 10.61 & 0.988 \\
\hline
\end{tabular}

entropy for adsorption and desorption is showed in Figure 3. As in the range of moistures studied the law of compensation could be applied, the results were correlated in accordance with equation (8). The parameter $T_{n}$ that is called the isokinetic temperature was calculated by linear regression for all data sets within a 95\% confidence interval. The harmonic mean temperature $\left(T_{n}\right)$ was calculated from equation (9). According to KRUG, HUNTER \& GRIEGER $[13,14]$ a linear chemical compensation pattern exists only if $\mathrm{T}_{a} \neq$ $\mathrm{T}_{\mathrm{s}}$. The isokinetic temperature for adsorption and desorption of mango was found to be $463 \pm 4 \mathrm{~K}$ and $501 \pm$ $5 \mathrm{~K}$. The adjusted $\mathrm{r}^{2}$ value was 0.99 for all experimental data. The harmonic mean temperature was calculated as $322 \mathrm{~K}$, value significantly different from all values of $T_{\text {n }}$ described above, confirming the suitability of the isokinetic theory for water sorption of mango. According to LEFFLER [15], if $\mathrm{T}_{\mathrm{a}}>\mathrm{T}_{\mathrm{w}}$ the process is enthalpy driven, while if the opposite condition is observed $\left(\mathrm{T}_{\mathrm{a}}<\mathrm{T}_{\mathrm{n}}\right)$, the process is considered to be entropy-controlled.

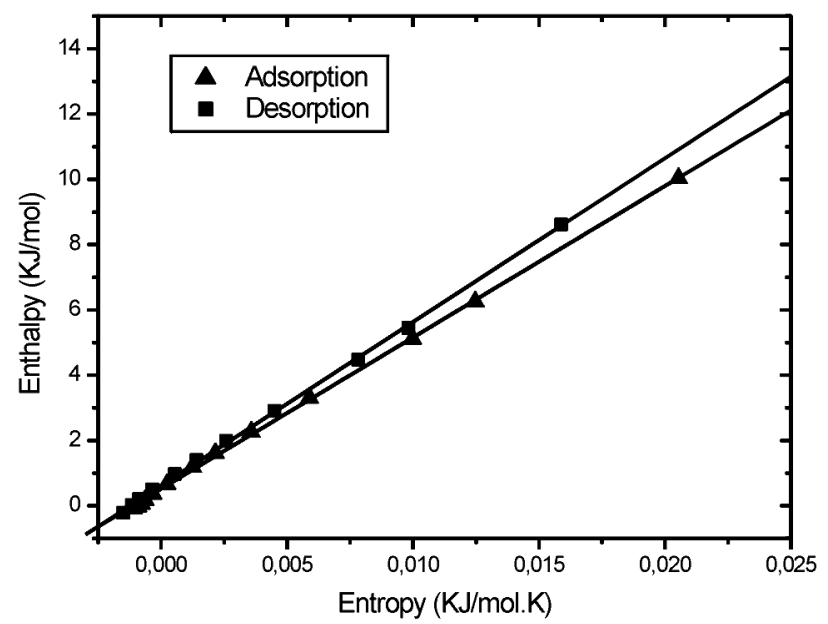

FIGURE 3 - Enthalpy-entropy relationship for water adsorption and desorption in mango; - , equation (8)

\section{4 - CONCLUSIONS}

The GAB isotherm model was found to be adequate for the description of the experimental data obtained for mango pulp. The equilibrium moisture content increased with decreasing temperature at constant 
water activity. The net isosteric heat of sorption was higher as the moisture content was reduced, the heat of adsorption being little higher than that of desorption at low moisture contents. An empirical exponential relationship could describe the heat of sorption dependence on the material moisture content. The enthalpy-entropy compensation or the isokinetic theory could be successfully applied to water sorption by mango pulp and suggests that this process could occur by enthalpy-controlled mechanisms.

\section{5 - REFERENCES}

[1] AGUERRE, R.J.; SUAREZ, C.; VIOLLAZ, P.E. Enthalpyentropy compensation in sorption phenomena: Application to the prediction of the effect of temperature on food isotherms. Journal of Food Science, v.51, p.1547-1549, 1986.

[2] ASSOCIATION OF OFFICIAL ANALYTICAL CHEMISTS. Official Methods of Analysis of AOAC. 15 ed. Washington DC, Assoc. Off. Agric. Chem., 1990.

[3] AYRANCI, E.; AYRANCI, G.; ZAFER, D. Moisture sorption isotherms of dried apricot, fig and raisin at $20^{\circ} \mathrm{C}$ and $36^{\circ}$ C. Journal of Food Science, v.55, n.6, p.1591-1593, 1990.

[4] BELL, R.P. Relations between the energy and entropy of solution and their significance. Trans. Faraday Soc., v.33, p.496-501, 1937.

[5] BERISTAIN, C.I.; GARCIA, H.S.; AZUARA, E. Enthalpyentropy compensation in food vapor adsorption. Journal of Food Engineering, v.30, p.405-415, 1996.

[6] CEPEA CENTRO DE ESTUDOS AVANÇADOS EM ECONOMIA APLICADA. Esalq- USP. Disponivel em : http:/ / www.cepea.esalq.usp.br. (25 dez. 2003).

[7] FERRO-FONTAN, C.; CHIRIFE, J.; SANCHO, E.; IGLESIAS, H.A. Analysis of a model for water sorption phenomena in foods. Journal of Food Science, v.47, p.1590-1594, 1982.

[8] GABAS, A.L.; TELIS-ROMERO, J.; MENEGALLI, F.C. Thermodynamic Models for Water Sorption by Grape Skin and Pulp. Drying Technology, v. 17, n.4\&5, p.961974, 1999.

[9] IGLESIAS, H.A.; CHIRIFE, J. Isosteric heats of water vapor sorption on dehydrated foods. Part I. Analysis of the differential heat curves. Lebensmittel-Wissens. und-Technol., 9, p.116-122, 1976.

[10] JOWITT, R.; ESCHER, F.; HALLSTOM, B.; MEFFERT, H.F.T.; SPIESS, W.E.L.; VOS, G. Physical Properties of Foods. London and New York : Applied Science Publishers, 1983.

[11] KIRANOUDIS, C.T.; MAROULIS, Z.B.; TSAMI, E.; MARINOS-KOURIS, D. Equilibrium moisture content and heat of desorption of some vegetables. Journal of Food Engineering, v.20, p.55-74, 1993.

[12] KIRANOUDIS, C.T.; TSAMI, E.; MAROULIS, Z.B.; MARINOS-KOURIS, D. Drying kinetics of some fruits. Drying Technology, v. 15, n.5, p.1399-1418, 1997.

[13] KRUG, R.R.; HUNTER, W.G.; GRIEGER, R.A. Enthalpyentropy compensation. 1 - Some fundamental statistical problems associated with the analysis of Van't Hoff and
Arrhenius data. J. Physical Chemistry, v.80, p.23352341, 1976.

[14] KRUG, R.R.; HUNTER, W.G.; GRIEGER, R.A. Enthalpyentropy compensation. 2 - Separation of the chemical from the statistical effect. J. Physical Chemistry, v.80, p. 2341-2351, 1976.

[15] LEFFLER, J.E. The Enthalpy-entropy relationship and its implications for organic chemistry. J. Organic Chemistry, v. 20, p.1202-1231, 1955.

[16] MADAMBA, P.S.; DRISCOLL, R.H.; BUCKLE, K.A. Enthalpy-entropy compensation models for sorption and browning of garlic. Journal of Food Engineering, v.28, p.109-119, 1996.

[17] MANINA, I., Fruticultura Tropical 2: Manga, Campinas, Ital, 1981.

[18] MAROULIS, Z.B.; TSAMI, E.; MARINOS-KOURIS, D.; SARAVACOS, G.D. Application of the GAB model to the moisture sorption isotherms for dried fruits. Journal of Food Engineering, v.7, p.63-78, 1988.

[19] MAZZA, G.; LEMAGUER, M. Water sorption properties of yellow globe onion. Can. Inst. Food Sci. Technol. J., v.11, p.189-193, 1978.

[20] MCLAUGHLIN, C.P.; MAGEE, T.R.A. The determination of sorption isotherm and the isosteric heats of sorption for potatoes. Journal of Food Engineering, v.35, p.267280, 1998

[21] RIVA, M.; MASI, P. The influence of drying conditions and pretreatments on permeability to water of grape skin.

Drying 86 - Proceedings of the Fifth International Symposium on Drying, 1986, Cap.1, Pag. 454.

[22] RIZVI, S.S.H. Thermodynamic properties of foods in dehydration. In: Engineering Properties of Foods, (Rao, M.A.; Rizvi, S.S.H. eds.) New York: Academic Press, 1995. Chap 4.

[23] SARAVACOS, G.D.; TSIOURVAS, D.A.; TSAMI, E. Effect of temperature on the water adsorption isotherms of Sultana raisins. Journal of Food Science, v. 51, n.2, p.381-383 and 387, 1986.

[24] TSAMI, E.; MAROULIS, Z.B.; MARINOS-KOURIS, D.; SARAVACOS, G.D. Heat of sorption of water in dried fruits. International Journal of Food Science and Technology, 25, 350-359, 1990.

[25] TSAMI, E. Net isosteric heat of sorption in dried fruits. Journal of Food Engineering, v. 14, p.327-335, 1991.

[26] WANG, N.; BRENNAN, J.G. Moisture sorption isotherm characteristics of potatoes at four temperatures. Journal of Food Engineering, v.14, p.269-287, 1991.

[27] ZHANG, X.; LIU, X.; GU, D.; ZHOU, W.; WANG, R.; LIU, P. Desorption isotherms of some vegetables. Journal of the Science and Food Agriculture, v.70, p.303-306, 1996.

\section{6 - ACKNOWLEDGMENT}

Authors wish to thank CAPES (Coordenação de Aperfeiçoamento de Pessoal de Nivel Superior), CNPq (Conselho Nacional de Desenvolvimento Científico e Tecnológico) - Proc. 300539/2003-7 and FAPESP (Fundação de Amparo à Pesquisa do Estado de São Paulo) - Proc. 99/07852-3 for financial support. 


\section{SYMBOLS}

a Water activity

C Constant in GAB model (eqn 1)

$\Delta \mathrm{G}$ Change in Gibbs free energy $(\mathrm{J} / \mathrm{mol})$

$\Delta \mathrm{H} \quad$ Change in enthalpy $(\mathrm{J} / \mathrm{mol})$

$\mathrm{K}$ Constant in GAB model (eqn 1)

n Number of isotherms

q. Net isosteric heat of sorption $(\mathrm{kJ} / \mathrm{mol})$

$\mathrm{R} \quad$ Universal gas constant $(8.314 \mathrm{~J} / \mathrm{mol} \mathrm{K})$

$\mathrm{r}^{2} \quad$ Fit determination coefficient for parameters $\mathrm{DH}_{\mathrm{c}}$ and $\mathrm{C}_{\mathrm{o}}$ in Table 2

$\mathrm{r}^{2}$ Fit determination coefficient for parameters $\mathrm{DH}_{*}$ and $\mathrm{k}$ in Table 2

$\Delta \mathrm{S} \quad$ Change in specific entropy $(\mathrm{J} / \mathrm{mol} \mathrm{K})$

$\mathrm{T}$ Absolute temperature (K)

$\mathrm{T}_{\mathrm{a}} \quad$ Estimated isokinetic temperature $(\mathrm{K})$

Var Statistical variance

X Moisture content

$\mathrm{X}_{\mathrm{w}} \quad$ Constant in GAB model (eqn 1)

$\lambda$ Heat of condensation of pure water $(\mathrm{kJ} / \mathrm{mol})$
Superscript

- Average

Subscripts

B Isokinetic

ds Dry solids

eq Equilibrium

hm Harmonic mean

m First layer

n Multilayers

o Inicial

w Water 